\title{
Mesenchymal Stem Cell Transplantation in Multiple Sclerosis
}

\author{
Jeffrey A. Cohen \\ Mellen Center, Neurological Institute, Cleveland Clinic, Cleveland, $\mathrm{OH}$, USA
}

\begin{abstract}
Mesenchymal stem cells (MSCs) are a pluripotent non-hematopoietic precursor cells that can be isolated from bone marrow and numerous other tissues, culture-expanded to purity, and induced to differentiate in vitro and in vivo into mesodermal derivatives. MSCs exhibit many phenotypic and functional similarities to pericytes. The immunomodulatory, tissue protective, and repairpromoting properties of MSCs demonstrated both in vitro and in animal models make them an attractive potential therapy for MS and other conditions characterized by inflammation and/or tissue injury. Other potential advantages of MSCs as a therapeutic include the relative ease of culture expansion, relative immunoprivilege allowing allogeneic transplantation, and their ability to traffic from blood to areas of tissue allowing intravascular administration. The overall published experience with MSC transplantation in MS is modest, but several small case series and preliminary studies yielded promising results. Several groups, including us, recently initiated formal studies of autologous, culture-expanded, bone-marrow-derived MSC transplantation in MS. Although there are several potential safety concerns, to date, the procedure has been well tolerated. Future studies that more definitively assess efficacy also will need to address several technical issues.
\end{abstract}

\section{Keywords}

Multiple sclerosis; Stem cell transplantation; Neuroprotection; Regeneration; Immunomodulation

\section{Introduction}

The multiple sclerosis (MS) disease process is complex and produces multifocal central nervous system (CNS) pathology with varying degrees of perivenular inflammation, demyelination, axonal transection, neuronal degeneration, and gliosis in both white and gray matter. Inflammatory mechanisms predominate in early stages reflected most directly in relapses and magnetic resonance imaging (MRI) lesion activity. Neurodegeneration is hypothesized to produce the gradual worsening in progressive MS. Although intrinsic repair processes exist in MS, they are unable to compensate sufficiently for ongoing damage in most patients. Currently approved MS treatments primarily reduce CNS inflammation.

\footnotetext{
(c) 2012 Elsevier B.V. All rights reserved.

Corresponding author at: Mellen Center, Cleveland Clinic, 9500 Euclid Avenue, Cleveland, OH, USA, 216-445-8110 (phone), 216-445-6259 (FAX), cohenj@ccf.org.

Publisher's Disclaimer: This is a PDF file of an unedited manuscript that has been accepted for publication. As a service to our customers we are providing this early version of the manuscript. The manuscript will undergo copyediting, typesetting, and review of the resulting proof before it is published in its final citable form. Please note that during the production process errors may be discovered which could affect the content, and all legal disclaimers that apply to the journal pertain.

Conflict of interest

Dr. Cohen received personal compensation for serving as a consultant for Teva and research support paid to his institution from Biogen Idec, Department of Defense, Genzyme, National Institutes of Health, National Multiple Sclerosis Society, Novartis, Receptos, Synthon, and Teva.
} 
Treatment strategies to prevent tissue damage and/or augment remyelination and axonal regeneration are greatly needed.

Besides hematopoietic stem cells, the bone marrow (BM) microenvironment contains pluripotent non-hematopoietic precursor cells that can be isolated, culture-expanded to purity, and induced to differentiate in vitro and in vivo into mesodermal derivatives [1,2]. These cells are referred as multipotent stromal cells or mesenchymal stem cells (MSCs). Cells with similar properties exist in a variety of other tissues, including adipose tissue, peripheral and umbilical cord blood, placenta, amniotic fluid, fetal tissues, synovial membrane, and deciduous teeth, but bone marrow MSCs are the best characterized. It is hypothesized that the normal MSC niche is the perivascular space, that MSCs correspond to pericytes, and their normal function is to maintain vascular and immunologic homeostasis and facilitate tissue repair $[3,4]$.

No single marker or combination specifically defines MSCs. Criteria proposed by the Mesenchymal and Tissue Stem Cell Committee of the International Society for Cellular Therapy [5] include: (1) plastic-adherence during in vitro expansion; (2) absence of hematopoietic surface markers (CD14, CD11b, CD19, CD34, CD45, and HLA-DR) and presence of CD73, CD90, and CD105 surface markers; and (3) ability to undergo in vitro differentiation into adipocytes, chondroblasts, and osteoblasts. MSCs elaborate a wide range of soluble immunoregulatory and trophic factors, reviewed in [6]. The immunomodulatory, tissue protective, and repair-promoting properties of MSCs described below make them an attractive potential therapy for MS and other neurologic disorders [7-10]. Other potential advantages of MSCs as a therapeutic include the relative ease of culture expansion, generally good safety profile, relative immunoprivilege allowing allogeneic transplantation, and their ability to traffic from blood to areas of tissue allowing intravascular administration.

\section{MSC transplantation in animal models}

The most studied animal model of MS is experimental autoimmune encephalomyelitis (EAE), in which immunization of susceptible species with myelin proteins or immunogenic myelin peptides in combination with adjuvant leads to multifocal inflammation and variable demyelination and axonal damage in the CNS. Depending on the nature of the immunogen and the genetic background of the animal, the course may be either relapsing-remitting similar to that seen in early MS or a more chronic as seen in progressive MS. This model has been informative in dissecting the immunologic mechanisms leading to tissue injury in MS and identifying potential therapeutic approaches.

In acute [11] and chronic [12-15] EAE mice, intravenous (IV) MSC administration ameliorated clinical manifestations, CNS inflammatory infiltration, demyelination, and axonal damage. Potential mechanisms include modulating both immunopathogenic processes and the response of the CNS to inflammatory injury. The potent immunomodulatory properties of MSCs are particularly relevant for MS [16-18]. They inhibit both innate and adaptive immunity, with a variety of immunosuppressive effects on T-cells, natural killer cells, B-cells, and antigen-presenting cells. MSCs inhibit T-cell proliferation stimulated by polyclonal activators, cognate antigen, and allogeneic mixed lymphocyte reaction [11,19-21]. MSC-derived soluble factors [11,22], cell-contact [23], and indirect effects through other cells including CD8+ regulatory cells [22] or antigenpresenting cells [24] have been implicated. Proposed MSC-derived immunomodulatory factors include inoleamine-2,3-dioxygenase, transforming growth factor- $\beta$, hepatocyte growth factor (HGF), nitric oxide, and soluble HLA-G [11,20,22,23,25-30]. MSCs also inhibit B-cell proliferation, expression of chemokine receptors, differentiation and production of $\operatorname{IgM}, \operatorname{IgG}$, and $\operatorname{Ig} \mathrm{A}[31]$. 
In EAE induced by peptides of myelin oligodendrocyte glycoprotein $\left(\mathrm{MOG}_{35-55}\right)$ or proteolipid protein ( $\mathrm{PLP}_{139-151}$ ), treatment with human BM-derived MSCs reduced the relative frequency of interferon-gamma (IFNY)-producing splenocytes, while the relative frequency of interleukin-4 (IL-4) producing cells was increased, suggesting that MSCs reduce inflammatory myelin-specific Th1 cells and increase inflammatory-inhibiting Th2 cells in EAE [32]. Following in vitro $\mathrm{MOG}_{35-55}$ stimulation of splenocytes from MSCtreated $\mathrm{MOG}_{35}-55$-induced EAE animals, the levels of Th1/Th17 inflammatory cytokines (IFNy, IL-17, IL-2, IL-12p70, and TNFa) were significantly reduced, while the levels of anti-inflammatory Th2 cytokines (IL-4 and IL-5) were significantly increased. Importantly, one of the cytokines showing the most prominent down-regulation was IL-17, which is strongly implicated in mediating the progression of disease in EAE [33]. In addition the in vitro proliferative response of splenocytes to $\mathrm{MOG}_{35-55}$ was markedly attenuated. In some studies of EAE, very few donor MSCs were detected in recipient CNS $[11,15]$. The majority of transplanted MSCs trafficked to lymph nodes and spleen. Taken together, these studies suggest that the clinical and pathological benefit appeared to be mediated by inhibition of peripheral encephalitogenic T-cells, as also was proposed for neurospheres in EAE [34].

However, several lines of evidence from animal studies suggest the beneficial effects of MSCs in EAE also may reflect a more direct influence of MSCs on neural cell responses to inflammatory CNS injury. Previously, it was thought that with appropriate stimuli MSCs may be capable of differentiating into non-mesenchymal lineages including neural cells [35]. Whether this phenomenon reflects trans-differentiation, ectopic marker expression, or cell fusion is currently unclear [36]. However, in studies using labeled MSCs, little evidence for the transplanted cells assuming neural fate was found [32]. A more likely possibility is that MSCs provide soluble factors that support development of intrinsic neural cells [37]. When neurospheres were generated from animals with ongoing EAE, the majority of the cells that develop in vitro were astrocytes, while the number of oligodendrocytes, their precursors, and neurons were relatively limited [32]. In MSC-treated EAE animals, the number of astrocytes was reduced and the proportions of oligodendrocytes and neurons were substantially increased. Since gliosis is thought to inhibit repair following CNS insults [38] and oligodendrocytes and their precursors are required for replacement following demyelination, these studies suggest that the functional improvement mediated by MSCs in EAE may reflect enhancement of endogenous repair processes. In other studies, histological analyses of MSC-treated EAE animals showed increases in the number of oligodendrocytes, enhanced remyelination, and improved axonal integrity in lesions [26,32].

In some studies, donor MSCs were identified in recipient CNS, particularly in inflammatory demyelinated areas [12-14]. Increased brain-derived neurotrophic factor production by CNS cells was demonstrated in transplanted animals, suggesting a possible mechanism of neuroprotective/repair-promoting actions in EAE. A recent study also implicated HGF as being functionally important in mediating MSC benefit in EAE [39]. Administration of human MSC conditioned medium (hMSC-CM) reduced functional deficits in $\mathrm{MOG}_{35-55^{-}}$ induced EAE and promoted development of oligodendrocytes and neurons. hMSC-CM was shown to contain HGF, and systemic administration of HGF promoted similar recovery in EAE. Antibodies directed against HGF and cMET (the receptor for HGF) blocked the efficacy of hMSC-CM and HGF.

Systemic HGF also accelerated remyelination in lysolecithin-induced demyelination in rat spinal cord lesions and slice cultures. Further support for the potential direct neural effects of MSC transplantation was shown in other, non-immune mediated animal models of neural injury. Experimental rodent stroke is the most-studied animal model of the neural repair potential of MSCs. Several general points can be concluded from these studies [40-46]. MSCs were capable of entering the CNS from the blood, survived in host tissue, migrated 
along fiber tracts, and preferentially accumulated in the area of damage or inflammation. Although some transplanted cells expressed neuronal or glial markers, the number was very small, and the cells maintained primitive morphology. Thus, transdifferentiation, neurogenesis, and integration probably were not the major mechanisms of improved functional recovery. Rather, the rapidity of the observed improvement, small number of transplanted MSCs in the CNS, and very small percentage with neuronal or glial features suggest that the benefit was due to neuroprotection, trophic effects, enhanced endogenous repair mechanisms, and/or angiogenesis mediated by elaboration of cytokines and growth factors, which would serve to magnify the benefit of the small number of cells getting into damaged tissue.

Other neural tissue models in which MSCs have been shown to be beneficial include focal spinal cord demyelination produced by $\mathrm{X}$-irradiation then ethidium bromide injection [47], sciatic nerve transection [48], SOD-G93A mouse model of amyotrophic lateral sclerosis [49,50], MPTP-induced parkinsonism [51], Huntington's disease model induced by striatal injection of quinolinic acid [52], cerebral contusion [53,54], and spinal cord contusion [5557]. Many other animal tissue injury models also have been studied and showed benefit. The wide range of tissue injury models in which MSCs are effective supports the hypothesis that they promote intrinsic repair mechanisms rather than differentiating into and directly replacing cellular elements. It is likely that distinct factors mediate benefit in different tissue injury models.

\section{Potential safety issues with MSC transplantation}

In general, MSC transplantation in humans, including with allogeneic MSCs, has been well tolerated [58]. Up to $10 \times 10^{6}$ cells per kg can be administered safely by the intravenous route [59]. Neither acute nor long-term clinically significant adverse events attributable to MSCs have been reported. Nevertheless, several potential adverse effects require close attention in planned trials.

\subsection{Infusion-related toxicity}

Close monitoring during infusion is necessary because of potential toxicity related to an allergic reaction to fetal bovine serum in the culture medium [60], dimethylsulfoxide in the freezing medium [61], or pulmonary embolic phenomena. Also, after injection, culture expanded MSCs can trigger an instant blood-mediated inflammatory reaction (IBMIR), mediated by innate immune mechanisms [62]. The likelihood of this reaction depends on the donor and increases with dose and number of passages. IBMIR potentially could compromise survival or function of infused MSCs or could trigger a hypersensitivity reaction or allergic phenomena.

\subsection{Infection}

Meticulous technique during bone marrow aspiration, culture-expansion, cryopreservation, thawing, and administration of MSCs is required to avoid infection related to contamination of the cell product. It also is possible that the immunosuppressive actions of MSCs could increase the risk of infection following transplantation.

\subsection{Ectopic tissue formation}

A potential concern with transplantation of any type of stem cell is ectopic tissue formation [63]. Ectopic tissue formation in the CNS was not seen when MSCs were administered IV to treat EAE $[11,15,64]$. However, when MSCs were administered via the intraventricular route, they migrated into the brain parenchyma and formed cellular masses with focal inflammation, local tissue damage, and collagen-fibronectin deposition, particularly when 
adminstered to animals with severe disease [65]. In humans, autopsies of 18 patients who received HLA-mismatched MSCs injected intravenously to treat complications of HSCT were performed, and 108 tissues from 15 patients examined by polymerase chain reaction [66]. No evidence of ectopic tissue formation was detected.

\subsection{Cancer}

Cancer related to malignant transformation of culture-expanded MSCs or permissive effects of immunosuppression is a theoretical concern, although it has not been reported to date. In the study cited above [66], no malignant tumors of MSC origin were detected.

\subsection{Autoimmunity or paradoxical disease activation}

Recent studies confirmed in vitro inhibition by MSC supernatants of Th1 T-cell proliferation and production of the Th1 cytokine IFNy but, surprisingly, showed stimulation of Th17 proliferation and production of IL-17A [21]. Similarly, polarization of MSCs into an immunosuppressive or pro-inflammatory phenotype based on stimulation of specific tolllike receptors also has been reported $[67,68]$. Thus, in vivo, MSC transplantation could have both pro- and anti-inflammatory effects in MS. This concern is particularly relevant as other treatments in MS have produced unanticipated autoimmune phenomena, e.g., alemtuzumab [69], or increased MS disease activity, e.g., TNFa blockers [70]. There was a recent report of a patient with MS who developed an acute disseminated encephalomyelitis-like illness six hours after the third of three monthly intrathecal injections of autologous MSCs [71].

\section{Therapeutic transplantation of MSCs in humans}

To date, the largest studies of therapeutic MSC transplantation have been in hematologic malignancy, breast cancer, graft vs. host disease, and acute and chronic ischemic heart disease, reviewed in [6]. There have been individual patients or small case series with a wide range of other conditions, including neurologic disorders such as acute stroke, spinal cord injury, cerebral trauma, Parkinson's disease, multisystem atrophy, and amyotrophic lateral sclerosis, reviewed in [10]. The published experience in MS is modest, but several preliminary studies reported promising results [72-76]. Recently, Connick et al. published the results of the only formal Phase 1/2a study to date in which 10 patients with secondary progressive MS and evidence of involvement of the anterior afferent visual pathways were treated with a single IV infusion of autologous culture-expanded, BM-derived MSCs (1.1$2.0 \times 10^{6}$ cells per $\mathrm{kg}$ ) [77]. Patients were followed in this open label study for up to 20 months pre-treatment and 10 months post-treatment. No severe or serious adverse events were reported. Preliminary efficacy analyses demonstrated benefit on some measures of structure and function of the visual pathways.

\section{Ongoing phase 1 study of MSC transplantation in MS}

Several other groups have initiated additional formal studies of MSC transplantation in MS. With funding from the US Department of Defense and National Institutes of Health, we are conducting a phase I trial and parallel mechanistic immunologic studies (ClinicalTrials.gov ID NCT00813969). The goal is to enroll 24 men and women ages 18-55, with active relapsing forms of MS, Expanded Disability Status Scale (EDSS) score 3.0-6.5, documented involvement of the anterior afferent visual system, and brain MRI demonstrating T2hyperintense lesions satisfying diagnostic criteria for MS [78,79]. Participants will be followed for two months pre-treatment and six months after IV infusion of autologous, culture-expanded, BM-derived MSCs $\left(1-2 \times 10^{6}\right.$ per kg) meeting strict release criteria for sterility, viability, and purity. Safety measures are summarized in Table 1, and exploratory efficacy assessments are summarized in Table 2. As of this writing, 20 participants have been enrolled. One participant's MSCs grew poorly in culture for unclear reasons. The target 
cell dose was attained in all other cases. All planned safety and efficacy assessments have been performed. MSC transplantation has been well tolerated with no significant toxicity.

Ancillary mechanistic immunologic studies will examine the in vivo effects of autologous MSC transplantation on MS relevant T-cell and B-cell immune responses at several time points before and after MSC transplantation. The immunologic effects of MSC

transplantation will be correlated with clinical and imaging measures of MS disease activity/ severity, and potential adverse effects. In vitro studies will evaluate molecular mechanisms of MSC-induced immunomodulation and whether there is any relationships between the range or magnitude of an individual participant's MSCs on his/her immune cells in vitro with the in vivo effects observed post-transplantation. Exploratory studies also will examine whether MSCs from MS patients and non-MS controls differ in their interactions with immune cells.

\section{Remaining questions and future directions}

MSC transplantation shows great promise as treatment for a variety of human conditions with inflammatory, ischemic, or traumatic tissue injury, including MS. Formal clinical trials are underway, predominantly focusing on safety or proof-of-concept. As future trials are developed to more directly assess efficacy, several important issues need to be considered.

6.1. Dose

There has been very little formal dose finding of MSC transplantation to date. The target dose in our study is $1-2 \times 10^{6}$ cells per kg, based on the MSC numbers achieved after culture expansion. This dose is in the range previously shown to be safe and efficacious in other conditions. We anticipate being able to achieve this cell yield in the majority of cases. MSC infusion up to $10 \times 10^{6}$ MSCs per $\mathrm{kg}$ has been shown to be safe in other conditions [59]. However, this dose is attained in only a subset of cultures.

\subsection{Optimal culture regimen}

Numerous technical factors related to bone marrow harvest, culture-expansion, cryopreservation, and thawing affect the yield, viability, function, and presumably efficacy of MSCs [80,81]. One important issue is the use of serum in the culture medium. There is extensive experience in the field culture expanding MSCs using medium containing fetal bovine serum (FBS). However, in addition to batch-to-batch variability, utilization of FBS raises several potential safety issues: anti-FBS antibodies reacting with FBS antigens adherent to MSCs conceivably could lead to rejection or infusion-related allergic reactions $[60,82]$, and FBS conceivably could transmit infection e.g., zoonoses or bovine spongiform encephalopathy. Therefore, development of serum-free culture methods is a priority. Prior to use in clinical trials, validation studies will be necessary to confirm a range of factors, including growth kinetics and yield, phenotype (surface marker expression), differentiation potential, immunomodulatory properties, lack of chromosomal abnormalities, and viability after freeze-thaw.

A second important consideration is whether MSCs could be primed in culture or genetically engineered to enhance survival, homing specific target tissues, or key functional features [83]. Two potential candidate modifications would be enhanced production of, for example, ciliary neurotrophic factor or HGF, both of which have been implicated in mediating the efficacy of MSCs in EAE [39,84]. 


\subsection{Route of administration}

After IV administration in rodents and primates, MSCs have been demonstrated by a variety of tracking techniques to distribute widely to normal tissues, predominantly lung but also liver, kidney, bone, skeletal muscle, heart, spleen, lymph node, thymus, and BM [53,54,8593]. MSCs have the ability to home from the blood to sites of tissue injury and inflammation, including in chronic cardiac rejection [91], localized prostatic inflammation [94], stroke [88], traumatic brain injury [53,54], demyelinated spinal cord lesions [95], intracranial glioma xenografts [96], and multiple tissues affected by acute radiation sickness [97]. In chronic murine EAE, labeled MSCs were detected in CNS in proportion to the degree of inflammation [12,13]. However, in other studies of murine EAE, labeled MSCs were detected in lymph node and spleen after IV administration but not brain parenchyma [11,15], suggesting the beneficial effects of MSCs occurred via peripheral immune mechanisms. The factors that attract MSCs to areas of tissue injury or inflammation and the mechanisms by which they enter these tissues are poorly understood.

Intra-arterial administration has been tested in acute and chronic ischemic heart disease in humans, and intracarotid injection has been tested in animal models of stroke to improve targeted delivery [98]. A recently published trial in multisystem atrophy included both IV and intracarotid administration [99]. Although the procedure was well tolerated clinically, brain MRI in some participants showed small T2 hyperintensities presumably representing ischemic lesions. Intranasal administration of MSCs has shown promise in animal studies $[100,101]$.

The study of Connick et al. [77] in MS employed IV administration. Others employed intrathecal administration, in some combined IV administration [74-76,102-104]. Because of safety and feasibility considerations, we elected to study IV administration in our trial. Sensitive tracking studies after human transplantation will be necessary to determine to extent to which MSCs traffic into CNS after different of routes of administration.

\subsection{Duration of benefit}

The extent of engraftment and duration of survival of donor MSCs after transplantation in humans is largely unknown. Donor MSCs have been difficult to detect in human tissues after transplantation. Long-term engraftment, albeit very modest, was demonstrated in a few studies [60,105-108]. In a recent study, autopsies of 18 patients who received HLAmismatched MSCs for complications of hematopoietic stem cell transplantation, including analysis of 108 tissues from 15 patients by polymerase chain reaction [66]. Donor DNA was detected in only rare tissues. There was no correlation between engraftment and magnitude of therapeutic response. The authors interpreted these findings to indicate a "hit and run" mechanism of action. In trials of graft vs. host disease, clinical benefit appeared to last for several months up to 1 year in a few patients [109]. At this time, there are no data concerning the duration of putative benefit following MSC transplantation in MS, but it is likely that it will be self-limited and that repeated administration may be required. However, repeat administration may increase the risk of sensitization, particularly with allogeneic MSCs.

\subsection{Use of autologous versus allogeneic MSCs for therapeutic transplantation in MS}

One important area of uncertainty is whether transplantation of autologous or allogeneic MSCs is preferable in disorders such as MS based on the theoretical concern that, due to the underlying disease or its treatment, autologous MSCs from MS patients could have "defective" immunomodulatory, tissue protective, or reparative capability. Allogeneic MSC transplantation appears feasible. MSCs are minimally immunogenic. In vitro, human MSCs do not stimulate proliferation or IFNY production by allogeneic T-cells $[20,23,24,110]$. They 
are not lysed and do not induce production of IFNY or TNFa by allogeneic cytotoxic T-cells [26,111]. In vivo, allogeneic and xenogeneic MSCs are not rejected in mice [22], and numerous studies demonstrate that allogeneic MSCs are not rejected in humans [109,112114]. This property allows for use of universal donor, allogeneic culture-expanded MSCs, an approach taken by several companies commercializing MSC therapy. Use of MSCs as an "off-the-shelf" reagent improves convenience and allows purified MSCs to be used to treat acute conditions, e.g., myocardial infarction, stroke, or MS relapse. Furthermore, this approach is clearly necessary to employ MSCs as replacement therapy in genetic disorders such as osteogenesis imperfecta, Hunter syndrome, metachromatic leukodystrophy, and Hurler syndrome $[59,106,115,116]$.

Although allogeneic transplantation appears feasible, it raises a number of practical concerns. First, "certification" of the donor to rule out infection and cancer must be comprehensive. Second, regulatory hurdles would be expected to be more difficult. Finally, although MSCs appear to be relatively immunoprivileged, allowing one-time transplantation of allogeneic cells without adverse events, there is evidence in animals that re-challenge with allogeneic MSCs induces sensitization, rejection, and immunologic memory responses [117]. Chronic disorders such as MS probably will require repeated MSC transplantation, which, thus, may be problematic.

Studies of MSCs isolated from patients with chronic diseases have yielded conflicting results. MSCs from patients with aplastic anemia [118], advanced osteoarthritis [119], and connective tissue diseases $[120,121]$ had altered proliferation and/or function. In contrast, in two studies, MSCs from patients with systemic lupus erythematosus, rheumatoid arthritis, systemic sclerosis, Sjogrens syndrome, polymyalgia rheumatic, or diabetes had similar surface phenotype, plaque-forming ability, differentiation capacity, ability to support hematopoiesis, and immunomodulatory properties as control MSCs, with no apparent effect on disease activity or immunosuppressant therapy [122,123]. BM stromal cells from $15 \mathrm{MS}$ patients supported hematopoiesis normally, with no effect of recent IFN $\beta$ treatment [124]. MSCs from five MS patients had similar proliferation, differentiation potential, and cell surface antigen expression as five healthy donors [125]. MSCs isolated from 10 MS patients had similar proliferation, differentiation capacity, toll-like receptor expression, immunomodulatory actions, ability to inhibit dendritic cell differentiation and activation, but significantly greater lipopolysaccharide-stimulated IP10 production compared to six healthy controls [126]. In summary, it remains uncertain whether MSCs from MS patients have altered properties and therapeutic potential. Therefore, studies of the phenotype and function of MSCs isolated as part of planned trials will be important to address this issue.

\section{Acknowledgments}

Funding

This work is supported by the US Department of Defense (W81XWH-10-1-0271), National Institutes of Health (1RO1 NS074787-01), National Multiple Sclerosis Society, Cleveland Clinic Research Programs Committee, and the Caroline Hurwitz Fund.

\section{Abbreviations}

$\begin{array}{ll}\text { BM } & \text { bone marrow } \\ \text { CNS } & \text { central nervous system } \\ \text { EAE } & \text { experimental autoimmune encephalomyelitis } \\ \text { EDSS } & \text { Expanded Disability Status Scale }\end{array}$




$\begin{array}{ll}\text { FBS } & \text { fetal bovine serum } \\ \text { HGF } & \text { hepatocyte growth factor } \\ \text { hMSC-CM } & \text { human mesenchymal stem cell conditioned medium } \\ \text { IBMIR } & \text { instant blood-mediated inflammatory reaction } \\ \text { IFN } & \text { interferon } \\ \text { IL } & \text { interleukin } \\ \text { IV } & \text { intravenous } \\ \text { MOG } & \text { myelin oligodendrocyte glycoprotein } \\ \text { MRI } & \text { magnetic resonance imaging } \\ \text { MS } & \text { multiple sclerosis } \\ \text { MSC } & \text { mesenchymal stem cell } \\ \text { TNFa } & \text { tumor necrosis factor-alpha }\end{array}$

\section{References}

1. Prockop DJ. Marrow stromal cells as stem cells for nonhematopoietic tissues. Science. 1997; 276:71-74. [PubMed: 9082988]

2. Pittenger MF, Mackay AM, Beck SC, Jaiswal RK, Douglas R, Mosca JD, et al. Multilineage potential of adult human mesenchymal stem cells. Science. 1999; 284:143-147. [PubMed: 10102814]

3. Da Silva Meirelles L, Caplan AI, Nardi NB. In search of the in vivo identity of mesenchymal stem cells. Stem Cells. 2008; 26:2287-2299. [PubMed: 18566331]

4. Crisan M, Yap S, Casteilla L, Chen C-W, Corselli M, Park TS, et al. A perivascular origin for mesenchymal stem cells in multiple human organs. Cell Stem Cell. 2008; 3:301-313. [PubMed: 18786417]

5. Dominici M, Le Blanc K, Mueller I, Slaper-Cortenbach I, Marini FC, Krause DS, et al. Minimal criteria for defining multipotent mesenchymal stromal cells. The International Society For Cellular Therapy position statement. Cytotherapy. 2006; 8:315-317. [PubMed: 16923606]

6. Mahad, D.; Planchon, SM.; Cohen, JA. Mesenchymal stem cell transplantation to treat multiple sclerosis. In: Cohen, JA.; Rudick, RA., editors. Multiple Sclerosis Therapeutics. 4th edition. Cambridge: Cambridge University Press; 2011. p. 520-534.

7. Sadan O, Melamed E, Offen D. Bone-marrow-derived mesenchymal stem cell therapy for neurodegenerative diseases. Expert Opin Biol Ther. 2009; 9:1487-1497. [PubMed: 19821796]

8. Siatskas C, Bernard CC. Stem cell and gene therapeutic strategies for the treatment of multiple sclerosis. Curr Mol Med. 2009; 9:992-1016. [PubMed: 19747118]

9. Freedman MS, Bar-Or A, Atkins HL, Karussis D, Frassoni F, Lazarus HM, et al. The therapeutic potential of mesenchymal stem cell transplantation as a treatment for multiple sclerosis: consensus report of the International MSCT Study Group. Mult Scler. 2010; 16:503-510. [PubMed: 20086020]

10. Maltman DJ, Hardy SA, Przyborski SA. Role of mesenchymal stem cells in neurogenesis and nervous system repair. Neurochem Int. 2011; 59:347-356. [PubMed: 21718735]

11. Zappia E, Casazza S, Pedemonte E, Benvenuto F, Bonanni I, Gerdoni E, et al. Mesenchymal stem cells ameliorate experimental autoimmune encephalomyelitis inducing T-cell anergy. Blood. 2005; 106:1755-1761. [PubMed: 15905186]

12. Karussis DM, Grigoriadis N, Ben-Hur T, Gouda-Kurkalli B, Mizrachi-Kol R, Einstein O, et al. Mesenchymal bone marrow stem cells migrate in CNS lesions in experimental autoimmune encephalomyelitis, differentiate into neuronal and glial line and downregulate EAE (abstract). Neurology. 2005; 64(Suppl 1):A407. 
13. Karussis D, Kassis I. Use of stem cells for the treatment of multiple sclerosis. Expert Rev Neurotherapeutics. 2007; 7:1189-1201.

14. Zhang J, Li Y, Chen J, Cui Y, Lu M, Elias SB, et al. Human bone marrow stromal cell treatment improves neurological functional recovery in EAE mice. Exp Neurol. 2005; 195:16-26. [PubMed: 15904921]

15. Gerdoni E, Gallo B, Casazza S, Musio S, Bonanni I, Pedemonte E, et al. Mesenchymal stem cells effectively modulate pathogenic immune response in experimental autoimmune encephalomyelitis. Ann Neurol. 2007; 61:219-227. [PubMed: 17387730]

16. Le Blanc K, Ringden O. Immunobiology of human mesenchymal stem cells and future use in hematopoietic stem cell transplantation. Biol Blood Marrow Transplant. 2005; 11:321-334. [PubMed: 15846285]

17. Uccelli A, Moretta L, Pistoia V. Immunoregulatory function of mesenchymal stem cells. Eur J Immunol. 2006; 36:2566-2573. [PubMed: 17013987]

18. Newman RE, Yoo D, LeRoux MA, Danilkovitch-Miagkova A. Treatment of inflammatory diseases with mesenchymal stem cells. Inflammation and Allergy - Drug Targets. 2009; 8:110 123. [PubMed: 19530993]

19. Bartholomew A, Sturgeon C, Siatskas M, Ferrer K, McIntosh K, Patil S, et al. Mesenchymal stem cells suppress lymphocyte proliferation in vitro and prolong skin graft survival in vivo. Exp Hematol. 2002; 30:42-48. [PubMed: 11823036]

20. Le Blanc K, Tammik L, Sundberg B, Haynesworth SE, Ringden O. Mesenchymal stem cells inhibit and stimulate mixed lymphocyte cultures and mitogenic responses independently of the major histocompatability complex. Scand J Immunol. 2003; 57:11-20. [PubMed: 12542793]

21. Darlington PJ, Boivin M-N, Renoux C, Francois M, Galipeau J, Freedman MS, et al. Reciprocal Th1 and Th17 regulation by mesenchymal stem cells: implications for MS. Ann Neurol. 2010; 68:540-545. [PubMed: 20661924]

22. Djouad F, Pience P, Bony C, Troplel P, Apparailly F, Sany J, et al. Immunosuppressive effect of mesenchymal stem cells favors tumor growth in allogeneic animals. Blood. 2003; 102:3837-3844. [PubMed: 12881305]

23. Krampera M, Glennie S, Dyson J, Scott D, Laylor R, Simpson E, Dazzi F. Bone marrow mesenchymal stem cells inhibit the response of naive and memory antigen-specific $\mathrm{T}$ cells to their cognate peptide. Blood. 2003; 101:3722-3729. [PubMed: 12506037]

24. Beyth S, Borovsky Z, Mevorach D, Liebergall M, Gazit Z, Aslan H, et al. Human mesenchymal stem cells alter antigen-presenting cell maturation and induce T-cell unresponsiveness. Blood. 2005; 105:2214-2219. [PubMed: 15514012]

25. Di Nicola M, Carlo-Stella C, Magni M, Milanesi M, Longoni PD, Matteucci P, et al. Human bone marrow stromal cells suppress T-lymphocyte proliferation induced by cellular or nonspecific mitogenic stimuli. Blood. 2002; 99:3838-3843. [PubMed: 11986244]

26. Rasmusson I, Ringden O, Sundberg B, Le Blanc K. Mesenchymal stem cells inhibit the formation of cytotoxic T lymphocytes, but not activated cytotoxic T lymphocytes or natural killer cells. Transplantation. 2003; 76:1208-1213. [PubMed: 14578755]

27. Tse WT, Pendleton JD, Beyer WM, Egalka MC, Guinan EC. Suppression of allogeneic T-cell proliferation by human marrow stromal cells: implications in transplantation. Transplantation. 2003; 75:389-397. [PubMed: 12589164]

28. Le Blanc K, Rasmusson I, Gotherstrom C, Seidel C, Sundberg B, Sundin M, et al. Mesenchymal stem cells inhibit the expression of CD25 (interleukin-2 receptor) and CD38 on phytohaemagglutinin-activated lymphocytes. Scand J Immunol. 2004; 60:307-315. [PubMed: 15320889]

29. Chabannes D, Hill M, Merieau E, Rossignol J, Brion R, Soulillou JP, et al. A role for heme oxygenase-1 in the immunosuppressive effect of adult rat and human mesenchymal stem cells. Blood. 2007; 110:3691-3694. [PubMed: 17684157]

30. Nasef A, Mathieu N, Chapel A, Frick J, Francois S, Mazurier C, et al. Immunosuppressive effects of mesenchymal stem cells: involvement of HLA-G. Transplantation. 2007; 84:231-237. [PubMed: 17667815] 
31. Corcione A, Benvenuto F, Ferretti E, Giunti D, Cappiello V, Cazzanti F, et al. Human mesenchymal stem cells modulate B-cell functions. Blood. 2006; 107:367-372. [PubMed: 16141348]

32. Bai L, Lennon DP, Eaton V, Maier K, Caplan AI, Miller SD, Miller RH. Human bone marrowderived mesenchymal stem cells induce Th2-polarized immune response and promote endogenous repair in animal models of multiple sclerosis. Glia. 2009; 57:1192-1203. [PubMed: 19191336]

33. Zepp J, Wu L, Li X. IL-17 receptor signaling and T helper 17-mediated autoimmune demyelinating disease. Trends in Immunology. 2011; 32:232-239. [PubMed: 21493143]

34. Einstein O, Fainstein N, Vaknin I, Mizrachi-Kol R, Reinhartz E, Grigoriadis N, et al. Neural precursors attenuate autoimmune encephalomyelitis by peripheral immunosuppression. Ann Neurol. 2007; 61:209-218. [PubMed: 17187374]

35. Jiang Y, Jahagirdar BN, Reinhardt RL, Schwartz RE, Keene CD, Ortiz-Gonzalez XR, et al. Pluripotency of mesenchymal stem cells derived from adult marrow. Nature. 2002; 418:41-49. [PubMed: 12077603]

36. Rutenberg MS, Hamazaki T, Singh AM, Terada N. Stem cell plasticity, beyond alchemy. Int J Hematol. 2004; 79:15-21. [PubMed: 14979473]

37. Rivera F, Couillard-Despres S, Pedre X, Ploetz S, Caioni M, Lois C, et al. Mesenchymal stem cells instruct oligodrogenic fate decision on adult neural stem cells. Stem Cells. 2006; 24:2209-2219. [PubMed: 16763198]

38. Fuller ML, DeChant AK, Rothstein B, Caprariello A, Wang R, Hall AK, Miller RH. Bone morphogenetic proteins promote gliosis in demyelinating spinal cord lesions. Ann Neurol. 2007; 62:288-300. [PubMed: 17696121]

39. Bai L, Lennon DP, Caplan AI, DeChant A, Hecker J, Kranso J, et al. Hepatocyte growth factor mediates mesenchymal stem cell-induced recovery in multiple sclerosis models. Nat Neurosci. 2012; 15:862-870. [PubMed: 22610068]

40. Brass LM. Bone marrow for the brain? Exp Neurol. 2006; 199:16-19. [PubMed: 16696974]

41. Bliss T, Guzman R, Daadi M, Steinberg GK. Cell transplantation therapy for stroke. Stroke. 2007; 38:817-826. [PubMed: 17261746]

42. Phinney DG, Isakova I. Plasticity and therapeutic potential of mesenchymal stem cells in the nervous system. Curr Pharm Des. 2005; 11:1255-1265. [PubMed: 15853682]

43. English D, Klasko SK, Sanberg PR. Elusive mechanisms of "stem-cell-mediated repair of cerebral damage. Exp Neurol. 2006; 199:10-15. [PubMed: 16730352]

44. Phinney DG, Prockop DJ. Mesenchymal stem/multipotent stromal cells: the state of transdifferentiation and modes of tissue repair - current views. Stem Cells. 2007; 25:2896-2902. [PubMed: 17901396]

45. Chopp M, Li Y, Zhang J. Plasticity and remodeling of brain. J Neurol Sci. 2008; 265:97-101. [PubMed: 17610903]

46. Dharmasaroja P. Bone marrow-derived mesenchymal stem cells for the treatment of ischemic stroke. J Clin Neurosci. 2009; 16:12-20. [PubMed: 19017556]

47. Akiyama Y, Radtke C, Honmou O, Kocsis JD. Remyelination of the spinal cord following intravenous delivery of bone marrow cells. Glia. 2002; 39:229-236. [PubMed: 12203389]

48. Dezawa M, Takahashi I, Esaki M, Takano M, Sawada H. Sciatic nerve regeneration in rats induced by transplantation of in vitro differentiated bone-marrow stromal cells. Eur J Neurosci. 2001; 14:1771-1776. [PubMed: 11860471]

49. Zhao C-P, Zhang C, Zhou S-N, Xie Y-M, Wang Y-H, Huang H, et al. Human mesenchymal stromal cells ameliorate the phenotype of SOD1-G93A ALS mice. Cytotherapy. 2007; 9:414-426. [PubMed: 17786603]

50. Zhang C, Zhou C, Teng J-J, Zhao R-L, Song Y-Q. Multiple administrations of human marrow stromal cells through cerebrospinal fluid prolong survival in a transgenic mouse model of amyotrophic lateral sclerosis. Cytotherapy. 2009; 11:299-306. [PubMed: 19333801]

51. Li Y, Chen J, Wang L, Zhang L, Lu M, Chopp M. Intracerebral transplantation of bone marrow stromal cells in a 1-methyl-4-phenyl-1,2,3,6-tetrahydropyridine mouse model of Parkinson's disease. Neurosci Lett. 2001; 315:67-70. [PubMed: 11742717] 
52. Sadan O, Shemesh N, Barzilay R, Bahat-Stromza M, Melamed E, Cohen Y, Offen D. Migration of neurotrophic factor-secreting mesenchymal stem cells toward a quinolinic acid lesion as viewed by magnetic resonance imaging. Stem Cells. 2008; 26:2542-2551. [PubMed: 18635865]

53. Mahmood A, Lu D, Wang L, Li Y, Lu M, Chopp M. Treatment of traumatic brain injury in female rats with intravenous administration of bone marrow stromal cells. Neurosurgery. 2001; 49:11961204. [PubMed: 11846913]

54. Lu P, Tuszynski MH. Can bone marrow-derived stem cells differentiate into functional neurons? Exp Neurol. 2005; 193:273-278. [PubMed: 15869931]

55. Chopp M, Zhang XH, Li Y, Wang L, Chen J, Lu D, et al. Spinal cord injury in rat: treatment with bone marrow stromal cell transplantation. Neuroreport. 2000; 11:3001-3005. [PubMed: 11006983]

56. Hofstetter CP, Schwarz EJ, Hess D, Widenfalk J, El Manira A, Prockop DJ, Olson L. Marrow stromal cells form guiding strands in the injured spinal cord and promote recovery. Proc Natl Acad Sci U S A. 2002; 99:2199-2204. [PubMed: 11854516]

57. Wu S, Suzuki Y, Ejiri Y, Noda T, Bai H, Kitada M, et al. Bone marrow stromal cells enhance differentiation of cocultured neurosphere cells and promote regeneration of injured spinal cord. J Neurosci Res. 2003; 72:343-351. [PubMed: 12692901]

58. Lalu MM, McIntyre L, Pugliese C, Fergusson D, Winston BW, Marshall JC, et al. Safety of cell therapy with mesenchymal stromal cells (SafeCell): a systematic review and meta-analysis of clinical trials. PLoS ONE. 2012; 7:e47559. [PubMed: 23133515]

59. Koc ON, Day J, Nieder M, Gerson SL, Lazarus HM, Krivit W. Mesenchymal stem cells. Allogeneic mesenchymal stem cell infusion for treatment of metachromatic leukodystrophy (MLD) and Hurler syndrome (MPS-IH). Bone Marrow Transplant. 2002; 30:215-222. [PubMed: 12203137]

60. Horwitz EM, Gordon PL, Koo WKK, Marx JC, Neel MD, McNall RY, et al. Isolated allogeneic bone marrow-derived mesenchymal cells engraft and stimulate growth in children with osteogenesis imperfecta: Implications for cell therapy of bone. Proc Natl Acad Sci U S A. 2002; 99:8932-8937. [PubMed: 12084934]

61. Chen-Plotkin AS, Vossel KA, Samuels MA, Chen MH. Encephalopathy, stroke and myocardial infarction with DMSO use in stem cell transplantation. Neurology. 2007; 68:859-861. [PubMed: 17353475]

62. Moll G, Rasmusson-Duprez I, von Bahr L, Connolly-Andersen A-M, Elgue G, Funke L, et al. Are therapeutic human mesenchymal stromal cells compatible with human blood? Stem Cells. 2012; 30:1565-1574. [PubMed: 22522999]

63. Breitbach M, Bostani T, Roell W, Xia Y, Dewald O, Nygren JN, et al. Potential risks of bone marrow cell transplantation into infarcted hearts. Blood. 2007; 110:1362-1369. [PubMed: 17483296]

64. Kassis I, Grigoriadis N, Gowda-Kurkalli B, Mizrachi-Kol R, Ben-Hur T, Slavin S, et al. Neuoprotection and immunomodulation with mesenchymal stem cells in chronic experimental autoimmune encephalomyelitis. Arch Neurol. 2008; 65:753-761. [PubMed: 18541795]

65. Grigoriadis N, Lourbopoulos A, Lagoudaki R, Frischer J-M, Polyzoidou E, Touloumi O, et al. Variable behavior and complications of autologous bone marrow mesenchymal stem cells transplanted in experimental autoimmune encephalomyelitis. Exp Neurol. 2011; 230:78-89. [PubMed: 21440544]

66. von Bahr L, Batsis I, Moll G, Hagg M, Szakos A, Sundberg B, et al. Analysis of tissues following mesenchymal stromal cell therapy in humans indicate limited long-term engraftment and no ectopic tissue formation. Stem Cells. 2012; 30:557-564.

67. DelaRosa O, Lombardo E. Modulation of adult mesenchymal stem cells activity by toll-like receptors: implications on therapeutic potential. Mediators Inflamm. 2010; 2010865601.

68. Waterman RS, Tomchuck SL, Henkle SL, Betancourt AM. A new mesenchymal stem cell (MSC) paradigm: polarization into a pro-inflammatory MSC1 or an immunosuppressive MSC2 phenotype. PLoS ONE. 2010; 5:e10088. [PubMed: 20436665] 
69. Coles AJ, Compston DA, Selmaj KW, Lake SL, Moran S, et al. The CAMMS223 Trial Investigators. Alemtuzumab vs.interferon beta-1a in early multiple sclerosis. N Engl J Med. 2008; 359:1786-1801. [PubMed: 18946064]

70. The Lenercept Multiple Sclerosis Study Group, The University of British Columbia MS/MRI Analysis Group. TNF neutralization in MS. Results of a randomized, placebocontrolled multicenter study. Neurology. 1999; 53:457-465. [PubMed: 10449104]

71. Kishk NA, Abokrysha NT, Gabr H. Possible induction of acute disseminated encephalomyelitis (ADEM)-like demyelinating illness by intrathecal mesenchymal stem cell injection. J Clin Neurosci. 2012 http://dx.doi.org/10.1016/j.jocn.2012.04.013.

72. Moyeddin Bonab M, Yazdanbakhsh S, Loft J, Alimoghaddom K, Talebian F, Hooshmand F, et al. Does mesenchymal stem cell therapy help multiple sclerosis patients? Iran J Immunol. 2007; 4:5057. [PubMed: 17652844]

73. Scolding N, Marks D, Rice C. Autologous mesenchymal bone marrow stem cells: practical considerations. J Neurol Sci. 2008; 265:111-115. [PubMed: 17904159]

74. Riordan NH, Ichim TE, Min W-P, Wang H, Solano F, Lara F, et al. Non-expanded adipose stromal vascular fraction cell therapy for multiple sclerosis. J Transl Medi. 2009; 7:29.

75. Yamout B, Hourani R, Salti H, Barada W, El-Hajj T, Al-Katoubi A, et al. Bone marrow mesenchymal stem cell transplantation in patients with multiple sclerosis: A pilot study. $\mathrm{J}$ Neuroimmunol. 2010; 227:185-189. [PubMed: 20728948]

76. Karussis D, Karageorgiou C, Vaknin-Dembinsky A, Gowda-Kurkalli B, Gomori JM, Kassis I, et al. Safety and immunologic effects of mesenchymal stem cell transplantation in patients with multiple sclerosis and amyotrophic lateral sclerosis. Arch Neurol. 2010; 67:1187-1194. [PubMed: 20937945]

77. Connick P, Kolappan M, Crawley C, Webber DJ, Patani R, Michell AW, et al. Autologous mesenchymal stem cells for the treatment of secondary progressive multiple sclerosis: an openlabel phase 2a proof-of-concept study. Lancet Neurology. 2012; 11:150-156. [PubMed: 22236384]

78. Barkhof F, Rocca M, Francis G, Van Waesberghe JHTM, Uitehaag BMJ, Hommes OR, et al. Validation of diagnostic magnetic resonance imaging criteria for multiple sclerosis and response to interferon $\beta 1$ a. Ann Neurol. 2003; 53:718-724. [PubMed: 12783417]

79. Tintore M, Rovira M, Rio J, Nos C, Grive E, Sastre-Garriga J, et al. New diagnostic criteria for multiple sclerosis. Application in first demyelinating episode. Neurology. 2003; 60:27-30. [PubMed: 12525713]

80. Neuhuber B, Swanger SA, Howard L, Mackay AM, Fischer I. Effect of plating density and culture time on bone marrow stromal cell characteristics. Exp Hematol. 2008; 36:1176-1185. [PubMed: 18495329]

81. Samuelsson H, Ringden O, Lonnies H, Le Blanc K. Optimizing in vitro conditions for immunomodulation and expansion of mesenchymal stromal cells. Cytotherapy. 2009; 11:129-136. [PubMed: 19152151]

82. Sundin M, Ringden O, Sundberg B, Nava S, Gotherstrom C, Le Blanc K. No alloantibodies against mesenchymal stromal cells, but presence of anti-fetal calf serum antibodies, after transplantation in allogeneic hematopoietic stem cell recipients. Haematologia (Budap). 2007; 92:1208-1215.

83. Wagner J, Kean T, Young RG, Dennis JE, Caplan AI. Optimizing mesenchymal stem cell-based theraputics. Curr Op Biotech. 2009; 20:1-6.

84. Lu Z, Hu X, Jhu C, Wang D, Zheng X, Liu Q. Overexpression of CNTF in mesenchymal stem cells reduces demyelination and induces clinical recovery in experimental autoimmune encephalomyelitis mice. J Neuroimmunol. 2008; 206:58-69. [PubMed: 19081144]

85. Pereira RF, Halford KW, O'Hara MD, Leeper DB, Sokolov BP, Pollard MD, et al. Cultured adherent cells from marrow can serve as long-lasting precursor cells for bone, cartilage, and lung in irradiated mice. Proc Natl Acad Sci U S A. 1995; 92:4857-4861. [PubMed: 7761413]

86. Pereira RF, O'Hara MD, Laptev AV, Halford KW, Pollard MD, Class R, et al. Marrow stromal cells as a source of progenitor cells for nonhematopoietic tissues in transgenic mice with a phenotype of osteogenesis imperfecta. Proc Natl Acad Sci U S A. 1998; 95:1142-1147. [PubMed: 9448299] 
87. Li Y, Hisha H, Inaba M. Evidence for migration of donor bone marrow stromal cells into recipient thymus after bone marrow transplantation plus bone grafts: A role of stromal cells in positive selection. Exp Hematol. 2000; 28:950-960. [PubMed: 10989196]

88. Chen J, Li Y, Wang L, Zhang Z, Lu D, Lu M, Chopp M. Therapeutic benefit of intravenous administration of bone marrow stromal cells after cerebral ischemia in rats. Stroke. 2001; 32:1005-1011. [PubMed: 11283404]

89. Devine SM, Bartholomew AM, Mahmud N, Nelson M, Patil S, Hardy W, et al. Mesenchymal stem cells are capable of homing to the bone marrow of non-human primates following systemic infusion. Exp Hematol. 2001; 29:244-255. [PubMed: 11166464]

90. Gao J, Dennis JE, Muzic RF, Lundberg M, Caplan AI. The dynamic in vivo distribution of bone marrow-derived mesenchymal stem cells after infusion. Cells Tissues Organs. 2001; 169:12-20. [PubMed: 11340257]

91. Wu GD, Nolta JA, Jin Y-S, Barr ML, Yu H, Starnes VA, Cramer DV. Migration of mesenchymal stem cells to heart allografts during chronic rejection. Transplantation. 2003; 75:679-685. [PubMed: 12640309]

92. Allers C, Sierralta WD, Neubauer S, Rivera F, Minguell JJ, Conget PA. Dynamic of distribution of human bone marrow-derived mesenchymal stem cells after transplantation into adult unconditioned mice. Transplantation. 2004; 78:503-508. [PubMed: 15446307]

93. Niemeyer P, Vohrer J, Schmal H, Kasten P, Fellenberg J, Suedkamp NP, Mehlhorn AT. Survival of human mesenchymal stromal cells from bone marrow and adipose tissue after xenogenic transplantation in immunocompetent mice. Cytotherapy. 2008; 10:784-795. [PubMed: 18951271]

94. Sokolova IB, Zin'kova NN, Shvedova EV, Kruglyakov PV, Polyntsev DG. Distribution of mesenchymal stem cells in the area of tissue inflammation after transplantation of the cell material via different routes. Bull Exp Biol Med. 2007; 143:143-146. [PubMed: 18019033]

95. Inoue M, Honmou O, Oka S, Houkin K, Hashi K, Kocsis JD. Comparative analysis of remyelinating potential of focal and intravenous administration of autologous bone marrow cells into the rat demyelinated spinal cord. Glia. 2003; 44:111-118. [PubMed: 14515327]

96. Nakamizo A, Marini F, Amano T, Khan A, Studeny M, Gumoin J, et al. Human bone marrowderived mesenchymal stem cells in the treatment of gliomas. Cancer Res. 2005; 65:3307-3318. [PubMed: 15833864]

97. Chapel A, Bertho JM, Bensidhoum M, Fouillard L, Young RG, Frick J, et al. Mesenchymal stem cells home to injured tissues when co-infused with hematopoietic cells to treat a radiation-induced multi-organ failure syndrome. Journal of Gene Medicine. 2003; 5:1028-1038. [PubMed: 14661178]

98. Li Y, Chen J, Wang L, Lu M, Chopp M. Treatment of stroke in rat with intracarotid administration of marrow stromal cells. Neurology. 2001; 56:1666-1672. [PubMed: 11425931]

99. Lee PH, Lee JE, Kim H-S, Song SK, Lee HS, HS N, et al. A randomized trial of mesenchymal stem cells in multiple system atrophy. Ann Neurol. 2012; 72:32-40. [PubMed: 22829267]

100. Danielyan L, Schafer R, von Ameln-Mayerhofer A, Buadze M, Geisler J, Klopfer T, et al. Intranasal delivery of cells to the brain. Eur J Cell Biol. 2009; 88:315-324. [PubMed: 19324456]

101. Danielyan L, Schafer R, von Ameln-Mayerhofer A, Bernhard F, Verleysdonk S, Buadze M, et al. Therapeutic efficacy of intranasally delivered mesenchymal stem cells in a rat model of Parkinson disease. Rejuvenation Res. 2011; 14:3-16. [PubMed: 21291297]

102. Mohyeddin Bonab M, Yazdanbakhsh S, Lotfi J, Alimoghaddom K, Talebian F, Hooshmand F, et al. Does mesenchymal stem cell therapy help multiple sclerosis patients? Report of a pilot study. Iran J Immunol. 2007; 4:50-57.

103. Liang J, Zhang H, Hua B, Wang H, Wang J, Han ZC, Sun L. Allogeneic mesenchymal stem cells transplantation in treatment of multiple sclerosis. Mult Scler. 2009; 15:644-646. [PubMed: 19389752]

104. Rice CM, Mallam EA, Whone AL, Walsh P, Brooks DJ, Kane N, et al. Safety and feasibility of autologous bone marrow cellular therapy in relapsing-progressive multiple sclerosis. Clin Pharmacol Ther. 2010; 87:679-685. [PubMed: 20445531]

105. Koc ON, Peters C, Auborg P, Raghavan S, Dyhouse S, DeGasperi R, et al. Bone marrow-derived mesenchymal stem cells remain host-derived despite successful hematopoietic engraftment after 
allogeneic transplantation in patients with lysosomal and peroxisomal storage diseases. Exp Hematol. 1999; 27:1675-1681. [PubMed: 10560915]

106. Horwitz EM, Prockop DJ, Fitzpatrick LA, Koo WKK, Gordon PL, Neel M, et al. Transplantability and therapeutic effects of bone marrow-derived mesenchymal cells in children with osteogenesis imperfecta. Nat Med. 1999; 5:309-313. [PubMed: 10086387]

107. Ringden O, Uzunel M, Rasmusson I, Remberger M, Sundberg B, Lonnies H, et al. Mesenchymal stem cells for treatment of therapy-resistant graft-versus-host disease. Transplantation. 2006; 81:1390-1397. [PubMed: 16732175]

108. Dominici M, Marino R, Rasini V, Spano C, Paolucci P, Conte P, et al. Donor cell-specific osteopoiesis originates from a self-renewing stem cell with a limited regenerative contribution after transplantation. Blood. 2008; 111:4386-4391. [PubMed: 18182575]

109. Le Blanc K, Frassoni F, Ball L, Locatelli F, Roelofs H, Lewis I, et al. Mesenchymal stem cells for treatment of steroid-resistant, severe, acute graft-versus-host disease: a phase II study. Lancet. 2008; 371:1579-1586. [PubMed: 18468541]

110. Klyushnenkova E, Mosca JD, Zernetkina V, Majumdar MK, Beggs KJ, Simonetti DW, et al. T cell responses to allogeneic human mesenchymal stem cells: immunogenicity, tolerance, and suppression. J Biomed Sci. 2005; 12:47-57. [PubMed: 15864738]

111. Rasmusson I, Uhlin M, Le Blanc K, Levitsky V. Mesenchymal stem cells fail to trigger effector functions of cytotoxic T lymphocytes. J Leukoc Biol. 2007; 82:887-893. [PubMed: 17609339]

112. Kebriaei P, Isola L, Bahceci E, Holland K, Rowley S, McGuirk J, et al. Adult human mesenchymal stem cells added to corticosteroid therapy for the treatment of acute graftversushost disease. Biol Blood Marrow Transplant. 2009; 15:804-811. [PubMed: 19539211]

113. Hare JM, Traverse JH, Henry TD, Dib N, Strumpf RK, Schulman SP, et al. A randomized, double-blind, placebo-controlled, dose-escalation study of entravenous adult human mesenchymal stem cells (Prohymal) after acute myocardial infarction. J Am Coll Cardiol. 2009; 54:2277-2286. [PubMed: 19958962]

114. Liang J, Zhang H, Hua B, Wang H, Lu L, Shi S, et al. Allogenic mesenchymal stem cell transplantation in refractory systemic lupus erythematosus: a pilot clinical study. Annals of Rheumatic Disease. 2010; 69:1423-1429.

115. Horwitz EM, Prockop DJ, Gordon PL, Koo WKK, Fitzpatrick LA, Neel MD, et al. Clinical responses to bone marrow transplantation in children with severe osteogenesis perfecta. Blood. 2001; 97:1227-1231. [PubMed: 11222364]

116. Cahill RA, Jones OY, Klemperer M, Steele A, Mueller TO, El-Badri N, et al. Replacement of recipient stromal/mesenchymal cells after bone marrow transplantation using bone fragments and cultured osteoblast-like cells. Biol Blood Marrow Transplant. 2004; 10:709-717. [PubMed: 15389437]

117. Zangi L, Margalit R, Reich-Zeliger S, Bachar-Lustig E, Beilhack A, Negrin R, Reisner Y. Direct imaging of immune rejection and memory induction by allogeneic mesenchymal stromal cells. Stem Cells. 2009; 27:2865-2874. [PubMed: 19750539]

118. Bacigalupo A, Valle M, Podesta M, Pitto A, Zocchi E, De Flora A, et al. T-cell suppression mediated by mesenchymal stem cells is deficient in patients with severe aplastic anemia. Exp Hematol. 2005; 33:819-827. [PubMed: 15963858]

119. Murphy JM, Dixon K, Beck S, Fabian D, Feldman A, Barry F. Reduced chondrogenic and adipogenic activity of mesenchymal stem cells from patients with advanced osteoarthritis. Arthritis Rheum. 2002; 46:704-713. [PubMed: 11920406]

120. Del Papa N, Quirici N, Soligo D, Scavullo C, Cortiana M, Borsotti C, et al. Bone marrow endothelial progenitors are defective in systemic sclerosis. Arthritis Rheum. 2006; 54:26052615. [PubMed: 16868984]

121. Kastrinaki M-C, Sidiropoulos P, Roche S, Ringe J, Lehmann S, Kritikos H, et al. Functional, molecular and proteomic characterisation of bone marrow mesenchymal stem cells in rheumatoid arthritis. Ann Rheum Dis. 2008; 67:741-749. [PubMed: 17921184]

122. Bocelli-Tyndall C, Bracci L, Spagnoli G, Braccini A, Bouchenaki M, Ceredig R, et al. Bone marrow mesenchymal stromal cells (BM-MSCs) from healthy donors and auto-immune disease 
patients reduce the proliferation of autologous- and allogeneic-stimulated lymphocytes in vitro. Rheumatology (Oxford). 2007; 46:403-408. [PubMed: 16920750]

123. Larghero J, Farge D, Braccini A, Lecourt S, Scherberich A, Fois E, et al. Phenotypical and functional characteristics of in vitro expanded bone marrow mesenchymal stem cells from patients with systemic sclerosis. Ann Rheum Dis. 2008; 67:443-449. [PubMed: 17526552]

124. Papadaki HA, Tsagournisakis M, Mastorodemos V, Pontikoglou C, Damianaki A, Pyrovolaki K, et al. Normal bone marrow hematopoietic stem cell reserves and normal stromal cell function support the use of autologous stem cell transplantation in patients with multiple sclerosis. Bone Marrow Transplant. 2005; 36:1053-1063. [PubMed: 16205726]

125. Mallam E, Kemp K, Wilkins A, Rice C, Scolding N. Characterization of in vitro expanded bone marrow-derived mesenchymal stem cells from patients with multiple sclerosis. Mult Scler. 2010; 16:909-918. [PubMed: 20542920]

126. Mazzanti B, Aldinucci A, Biagioli T, Barilaro A, Urbani S, Dal Pozzo S, et al. Differences in mesenchymal stem cell cytokine profiles between MS patients and healthy donors: Implications for assessment of disease activity and treatment. J Neuroimmunol. 2008; 199:142-150. [PubMed: 18562015] 
Table 1

Safety monitoring in the ongoing phase 1 study of autologous MSC transplantation in MS.

\begin{tabular}{|c|c|}
\hline $\begin{array}{l}\text { General safety visits (adverse event review, concomitant medication review, vital } \\
\text { signs, oxygen saturation, general physical examination, blood chemistry, } \\
\text { hematology, and urinalysis) }\end{array}$ & $\begin{array}{l}\text { Screening; Baseline; Days 1, 4, 7, } 14 \text { and } 21 \text { after } \\
\text { infusion; and Months 1, 2, 3, and } 6\end{array}$ \\
\hline Vital signs, oxygen-saturation & $\begin{array}{l}\text { Prior to, immediate following, and hourly for } 6 \text { hours } \\
\text { post-infusion }\end{array}$ \\
\hline Serum pregnancy (females patients) & Screening, Baseline, and Months 1, 3, and 6 \\
\hline Chest X-ray & Screening, and Months 1 and 6 \\
\hline Electrocardiogram & Screening, and Months 1 and 6 \\
\hline $\begin{array}{l}\text { Clinical immunology studies: serologic studies (thyroid stimulating hormone, } \\
\text { anti-thyroglobulin antibodies, anti-microsomal antibodies, sedimentation rate, C- } \\
\text { reactive protein, anti-nuclear antibodies, SSA antibodies, SSB antibodies, } \\
\text { rheumatoid factor), quantitative immunoglobulin levels, and lymphocyte subsets } \\
\text { measured by flow cytofluorometry }\end{array}$ & Screening, and Months 1,3 , and 6 \\
\hline MRI: gadolinium-enhancing lesions, looking for disease activation & Screening; Month -1; Baseline; and Months 1, 2, 3, ar \\
\hline
\end{tabular}


Table 2

Exploratory efficacy assessments in the ongoing phase 1 study of autologous MSC transplantation in MS performed at Screening; Month -1; Baseline; and Months 1, 2, 3, and 6.

\begin{tabular}{|l|l|}
\hline $\begin{array}{l}\text { Participant global impression of clinical status by visual analog } \\
\text { scale }\end{array}$ & \\
\hline Relapse rate & $\begin{array}{l}\text { EDSS, MS Functional Composite, visual acuity, Sloan low-contrast } \\
\text { letter acuity }\end{array}$ \\
\hline Clinician-assessed neurologic impairment/disability & $\begin{array}{l}\text { T2-hyperintense, T1-hypointense, and gadolinium-enhancing lesions; } \\
\text { whole brain and gray matter atrophy; magnetization transfer imaging; } \\
\text { and diffusion tensor imaging }\end{array}$ \\
\hline Brain MRI & P100 latency \\
\hline Visual evoked potentials & $\begin{array}{l}\text { Overall mean and quadrantic peripapillary retinal nerve fiber layer } \\
\text { thickness, foveal thickness, macular volume, and segmented ganglion } \\
\text { cell layer thickness }\end{array}$ \\
\hline Optical coherence tomography &
\end{tabular}

